\title{
Marketing Distribution Analysis of Tilapia (Oreochromis Niloticus): A Case Study of a Production House in Liabuku Village, Bungi District, Baubau City
}

\author{
Abdul Hadi Bone ${ }^{1}$, Ismail Failu ${ }^{1}$, Bahtiar Hamar ${ }^{1}$, Siti Fara Darmatia ${ }^{2}$, Jayanti Olviana Repi ${ }^{2}$, \\ Faharani Yosianti $\mathrm{M}^{2}$ \\ Corresponding Email: hadibone86@gmail.com \\ ${ }^{1}$ Lecturer of Aquatic Resources Management, Faculty of Agriculture, Muhammadiyah \\ University of Buton, Indonesia \\ ${ }^{2}$ Student of Water Resources Management, Faculty of Agriculture, Muhammadiyah \\ University of Buton, Indonesia
}

Received: December 15, 2021

Revised: January 17, 2022

Accepted: January 23, 2022

\begin{abstract}
The area of Baubau City has an ocean area of 200 miles, has fishery potential that can support people's lives. This study aims to: (1) determine the marketing agency in the marketing distribution of tilapia; (2) Knowing what the marketing margin of tilapia is; (3) Analyzing strategies and policies for developing tilapia aquaculture. This research was carried out in a fish production house starting in July-September 2021. The research method used qualitative descriptive methods and literature searches. To analyze the marketing functions based on each marketing agency, while the distribution margin analysis is carried out by calculating marketing costs both at the consumer and producer level. The results showed that there were 3 marketing distribution patterns, namely: Pattern I (Producer-Consumer), Pattern II (ProducerRetailer-Consumer), Pattern III (Producer-Wholesale-Retailer-Consumer). The distribution level of tilapia marketing in channel pattern I is more dominantly used because the marketing distribution channel is relatively shorter and affordable so that it cuts the marketing distribution channel to the final consumer level, so as to reduce other additional costs.
\end{abstract}

Keywords: Tilapia (Oreochromis Niloticus), Marketing Analysis, SWOT

\section{Introduction}

The geographical condition of Indonesia as an archipelagic country, which is two-thirds of its territory is marine waters consisting of coastal seas, high seas, bays and straits, has a beach length of 95,181 km, with an area of 5.8 million waters, rich in marine and fish resources. The sea waters are wide and rich in types and potential for fisheries, the stretch of coastline is so wide that the seas and coastal areas contain rich and varied marine biological natural resources, such as fish, coral reefs, mangrove forests, and natural resources. which cannot be updated. Fish as a marine product source of animal protein Omega 3, Omega 6, and Omega 9. Omega 3 functions to help the development of the eyes, brain and nerves Omega 6 is beneficial for endocrine and hormonal, Omega 9 serves to relieve symptoms of inflammation joint and cholesterol stability (Santos 2020; Nigam et al., 2018; Innis, 2008). The protein found in fish is more digested and has a complete amino acid content. Conceptually, the agribusiness system can be interpreted as all activities carried out starting from procurement, distribution of production facilities to marketing the products produced by these businesses and related agroindustry. One of the agribusiness fields that has been developed is the fishery sector. The more consumption of fish in the market, it results in an increase in intense competition between farmers or cultivators in production (Ahmed \& Turchini, 2021; Szuwalski et al., 2020). In 
dealing with this situation, an appropriate marketing strategy is needed in order to complete the level of competition with other farmers and expand the market. One way to expand the market is by making efficient marketing effective and facilitating the flow of goods from producers to consumers (Singh et al., 2021), through marketing efficiency so that the price of fish in the market will increase and ultimately affect the increase in the profits of the fish farmers involved (Pilar et al., 2018; Ashlagi et al., 2018). Some research results related to fish marketing distribution strategies such as those carried out by Yuliyarabihati et al. (2014), with the research location in the Bauntung market, Banjarbaru, South Kalimantan, where the research results show a new strategy that can be applied in the marketing process, namely the need for regulations for structuring the location. Fish market in the dawn market and at the market behind the Banjarbaru market, especially for the improvement of the market and drainage, as well as storage tanks. It is necessary to monitor the quality of tilapia on a regular and continuous basis in order to provide protection for consumers. A special business group for fish traders is needed as a forum for its membership organization.

This study aims to determine (1) What is the channel pattern in the marketing distribution of tilapia; (2) What is the distribution margin of tilapia marketing; (3) Analyzing strategies and policies for developing tilapia aquaculture.

The benefits of research can add insight to carry out a better marketing distribution of tilapia and for the advancement of aquaculture business, as well as as a reference for policy making for the government to reduce the rate of tilapia imports through strategies to increase productivity, expand ponds, increase production efficiency, improve quality. and increased added value.

\section{Methods}

\section{Research Location and Design}

The research location was carried out purposively, namely at the fish production house of Mr. Hamzah in Liabuku Village, Bungi District, Baubau City which was carried out from July to September 2021. The selection of research locations was deliberately chosen because it is one of the developments of tilapia fish farming business. The research period includes the preparation stage (literature collection), data collection, data analysis to report preparation.

\section{Sample Method}

Sampling was carried out on tilapia cultivators (producers), in this case Mr. Hamzah as a supplier of tilapia seeds to consumers and retail/traveling traders. Determination of the number of samples based on the number of retailers who came to buy at the tilapia production house and was selected randomly, namely a number of 50 respondents.

\section{Data Collection}

The types of data used are primary and secondary data. Primary data were collected through questionnaires and direct interviews with producers and retailers who sell tilapia to the market and mobile traders who sell tilapia to villages. While the secondary data includes the state of the area (geographical and administrative), environmental conditions and social conditions of the community obtained from the relevant agencies (BPS \& Fisheries and Marine Service of Baubau City).

\section{Data Analysis}

The analysis used in this study is in accordance with the objectives to be achieved, namely distribution margin analysis, share analysis and SWOT analysis.

\section{Results and Discussion}




\section{Marketing Channel}

The results showed that there were three patterns of tilapia distribution channels, namely: (1) Channel I (Producer-Consumer) pattern, which is the shortest and simplest form of marketing distribution channel pattern which is also known as direct distribution channel. In this pattern, consumers buy tilapia seeds directly from producers (tambak farmers) for Rp. 2,000 per head and there are 8 consumers found. (2) Channel II pattern (producer-retailer-consumer) is a form of distribution channel for tilapia marketing from producers to retailers and then to consumers. This pattern can also be referred to as an indirect distribution channel because an intermediary is found. Here the retailer directly purchases the pond farmers (producers) at a price of Rp. 2000,- per head and then the retailer resells it through their point of sale to the final consumer at a price of 5,000,- per head with a total of 30 retailers. (3) Channel III pattern (ProducerWholesale-Retailer-Consumer) is also called indirect distribution channel because it goes through several intermediaries, namely wholesalers, retailers and consumers. The distribution process starts from wholesalers buying themselves to producers at a price of Rp. 2000,- per head and then resold to retailers at a price of 4,000,- per head, then retailers resell it to final consumers at a price of 7,000,- per head and found wholesalers as many as 12 respondents. The following is the price of the Tilapia Marketing distribution channel:

Table 1. Price of Tilapia Distribution Channel

\begin{tabular}{|l|c|c|c|}
\hline \multicolumn{1}{|c|}{$\begin{array}{c}\text { Marketing Channel Pattern } \\
\text { Description }\end{array}$} & $\begin{array}{c}\text { Number of } \\
\text { respondents }\end{array}$ & $\begin{array}{c}\text { Average } \\
\text { Producer/tail } \\
\text { Selling Value }\end{array}$ & $\begin{array}{c}\text { Average } \\
\text { Selling } \\
\text { Value/tail to } \\
\text { end } \\
\text { Consumers }\end{array}$ \\
\hline $\begin{array}{l}\text { Pattern I Manufacturers - } \\
\text { Consumers } \\
\text { - Consumer }\end{array}$ & 8 & 2000 & 2000 \\
\hline $\begin{array}{l}\text { Pattern II Manufacturer-retailer- } \\
\text { Consumer }\end{array}$ & & & \\
- Retailer & 30 & 2000 & 5000 \\
- Consumer & 8 & - & - \\
\hline $\begin{array}{l}\text { Pattern III Manufacturers- } \\
\text { wholesalers-retailer-consumers }\end{array}$ & 12 & 2000 & - \\
- Big Merchant & 30 & - & 5000 \\
- Retailer & & - & 7000 \\
\hline Consumer & 8 & - & - \\
\hline Sum & $\mathbf{5 0}$ & & \\
\hline
\end{tabular}

Source: Primary Data Analysis, 2021

\section{Margin and Share Distribution Analysis}

Marketing margin is the difference between prices at the consumer level and prices at the producer level that occurs in the distribution channel of tilapia production in the Liabuku Village, Bungi District, Baubau City, which is calculated from the average price at 30 retailers and the average price at 12 traders. large, and the average price for 8 consumers who buy tilapia from cultivators (producers). In the distribution of tilapia in direct channels, the share received by pond farmers (producers) is Rp. 2,000, - per head (seedlings). Likewise, the price purchased at the final consumer level is Rp. 7,000, - per head. The highest marketing margin is Rp. 5.000,per head (seedling) and the lowest marketing margin is Rp. 3,000,- per head, while the average price at the producer is Rp. 2,000, - per head. And the price at the retailer is Rp. 5.000,- per 
head. From this price, retailers still incur costs such as the cost of pool water Rp. 550,- with distribution margin $18.34 \%$, share $11 \%$, oxygen cost Rp. 625 ,- margin distribution is $20.83 \%$, share is $12.5 \%$, plastic cost is $325,-$ margin distribution is $10.83 \%$ and share is $6.5 \%$. The following marketing margin and share can be seen in the table:

Table 2. Pattern I (Producer-Consumer)

\begin{tabular}{|c|l|c|c|c|}
\hline No & \multicolumn{1}{|c|}{ Marketing Institute } & (IDR/Kg) & $\begin{array}{c}\text { Margin Distribution } \\
(\mathbf{\%})\end{array}$ & $\begin{array}{c}\text { Share } \\
(\boldsymbol{\%})\end{array}$ \\
\hline 1 & $\begin{array}{l}\text { Fish Pond Farmer } \\
- \text { Selling price }\end{array}$ & $2.000,-$ & - & - \\
\hline 2 & $\begin{array}{l}\text { User } \\
- \text { Purchase Price }\end{array}$ & $2.000,-$ & & \\
\hline
\end{tabular}

Source: Primary Data Analysis, 2021

Table 3. Pattern II (Producer-Retailer-Final Consumer)

\begin{tabular}{|c|c|c|c|c|}
\hline No & Marketing Institute & $\begin{array}{c}\text { Price } \\
\text { (IDR/tail) }\end{array}$ & $\begin{array}{c}\text { Distribution of } \\
\text { Margin (\%) }\end{array}$ & $\begin{array}{c}\text { Share } \\
(\%)\end{array}$ \\
\hline 1 & $\begin{array}{c}\text { Fish Pond Farmer } \\
-\quad \text { Selling Price }\end{array}$ & $2000,-$ & & 40 \\
\hline 2 & $\begin{aligned} & \text { Retail Merchant } \\
& \text { - } \text { Purchase Price } \\
& \text { - } \text { Pool Water Costs } \\
& \text { - } \text { Cost of Oxygen } \\
& \text { - } \text { Cost of plastic } \\
& \text { - } \text { Advantage }\end{aligned}$ & $\begin{array}{r}2.000,- \\
550,- \\
625,- \\
325,- \\
1.500,-\end{array}$ & $\begin{array}{c}18,34 \\
20,83 \\
10,83 \\
50\end{array}$ & $\begin{array}{c}11 \\
12,5 \\
6,5 \\
30\end{array}$ \\
\hline 3 & $\begin{array}{c}\text { End Consumer } \\
-\quad \text { Buy }\end{array}$ & $5.000,-$ & & \\
\hline & Marketing Margin & $3.000 .-$ & 100 & 100 \\
\hline
\end{tabular}

Meanwhile, for the distribution of margin and share, wholesalers still incur costs such as the cost of pool water of Rp. 556,- distribution margin $11.12 \%$, share 7.94\%, oxygen cost Rp. 217,distribution margin $4.34 \%$, share $3.1 \%$, plastic cost Rp. 127 ,- distribution margin $2.54 \%$, share $1.81 \%$ and profit Rp. 1,100 , distribution margin $22 \%$, share $15.71 \%$. Here's a table presentation:

Table 4. Pattern III (Producer-Wholesale-Retailer-Final Consumer)

\begin{tabular}{|c|l|c|c|c|}
\hline No & \multicolumn{1}{|c|}{ Marketing Institute } & $($ IDR/Kg) & $\begin{array}{c}\text { Margin } \\
\text { Distribution } \\
(\boldsymbol{\%})\end{array}$ & $\begin{array}{c}\text { Share } \\
(\%)\end{array}$ \\
\hline 1 & Fish Pond Farmer & $2.000,-$ & & 28,57 \\
& - Selling Price & & & \\
\hline 2 & Big Trader & $2.000,-$ & 11,12 & 7,94 \\
& - Purchase Price & $556,-$ & 4,34 & 3,1 \\
& - Pool Water Cost & $217,-$ & 2,54 & 1,81 \\
& - Oxygen Cost & $127,-$ & 22 & 15,71 \\
& - Plastic Costs & $1.100,-$ & & \\
& - Advantages & $4.000,-$ & & \\
& - Selling Price & & & \\
\hline
\end{tabular}

Copyright $\odot$ 2022, Journal of Asian Multicultural Research for Economy and Management Study, Under the license CC BY-SA 4.0 


\begin{tabular}{|c|l|c|c|c|}
\hline 3 & Retail Merchant & $4.000,-$ & & \\
& - Purchase Price & $550,-$ & 11 & 7,86 \\
& -Pool Cost & $625,-$ & 12,5 & 8,93 \\
& - Oxygen Cost & $325,-$ & 6,5 & 4,65 \\
& - Plastic Costs & $1.500,-$ & 30 & 21,43 \\
\hline \multirow{2}{*}{4} & - Advantages & & & \\
& End Consumer & 7.000 & & \\
\hline & - Selling Price & 5.000 & 100 & 100 \\
\hline
\end{tabular}

Source: Primary Data Analysis, 2021

\section{Strategy and policy analysis Development}

The strategy and policy analysis used is the SWOT matrix as a tool to systematically identify factors, both internal factors including strengths and weaknesses and external factors including opportunities and threats being faced. The results of the SWOT analysis formulation are:

\section{Matrix of internal factors (IFE) and external factors (EFE)}

Table 5. Analysis of the IFE (Internal Factor Evaluation) matrix

\begin{tabular}{|c|c|c|c|c|}
\hline No & Strength & Weight & Rating & Shoes \\
\hline 1 & $\begin{array}{l}\text { The area of cultivation business land is very } \\
\text { adequate }\end{array}$ & 0,17 & 3 & 0,51 \\
\hline 2 & The potential of supporting natural resources & 0,11 & 3 & 0,33 \\
\hline 3 & $\begin{array}{l}\text { The location of the business is very strategic close } \\
\text { to the city of Baubau }\end{array}$ & 0,17 & 4 & 0,68 \\
\hline 4 & Social relationships with consumers are good. & 0,11 & 4 & 0,44 \\
\hline \multicolumn{2}{|r|}{ Sum } & & & 1,96 \\
\hline \multicolumn{2}{|r|}{ Debilitation } & & & \\
\hline 1 & Capital Limitations & 0,11 & 3 & 0,33 \\
\hline 2 & Tilapia cultivation business land is not certified & 0,11 & 2 & 0,22 \\
\hline 3 & Lack of market promotion activities & 0,11 & 3 & 0,33 \\
\hline 4 & Financial management has not been good & 0,05 & 2 & 0,10 \\
\hline 5 & $\begin{array}{l}\text { Lack of knowledge and mastery of new } \\
\text { technologies }\end{array}$ & 0,06 & 4 & 0,24 \\
\hline \multicolumn{2}{|r|}{ Sum } & & & 1,22 \\
\hline \multicolumn{2}{|r|}{ TOTAL } & $\mathbf{1 , 0 0}$ & & 3,18 \\
\hline
\end{tabular}

Table 6. Analysis of the EFE (External Factor Evaluation) matrix

\begin{tabular}{|c|c|c|c|c|}
\hline No & Chance & Weight & Rating & Shoes \\
\hline 1 & High demand for tilapia & 0,17 & 2 & 0,34 \\
\hline 2 & $\begin{array}{l}\text { Business development from the government and } \\
\text { academia }\end{array}$ & 0,17 & 3 & 0,51 \\
\hline 3 & The market opportunity is huge & 0,11 & 3 & 0,33 \\
\hline 4 & Good relationship with stakeholders & 0,11 & 2 & 0,22 \\
\hline \multicolumn{2}{|r|}{ Sum } & & & 1,40 \\
\hline \multicolumn{2}{|r|}{ Threat } & & & \\
\hline 1 & $\begin{array}{l}\text { Disease attacks that can decrease the quality and } \\
\text { quantity of tilapia fish }\end{array}$ & 0,11 & 2 & 0,22 \\
\hline 2 & Increase in the price of tilapia fish feed & 0,11 & 2 & 0,22 \\
\hline
\end{tabular}

Copyright $@$ 2022, Journal of Asian Multicultural Research for Economy and Management Study, Under the license CC BY-SA 4.0 


\begin{tabular}{|l|l|c|c|c|}
\hline 3 & $\begin{array}{l}\text { Difference in the price of tilapia from other } \\
\text { villages / regions }\end{array}$ & 0,05 & 2 & 0,10 \\
\hline 4 & $\begin{array}{l}\text { Competition for market demand for certain types } \\
\text { of tilapia }\end{array}$ & 0,17 & 1 & 0,17 \\
\hline \multicolumn{2}{|c|}{ Sum } & $\mathbf{1 , 0 0}$ & & $\mathbf{0 , 7 1}$ \\
\hline TOTAL
\end{tabular}

Based on the results of the IFE (Internal Factor Evaluation) matrix analysis, it shows that the strength (S) that has the greatest influence on the marketing distribution of tilapia is a very strategic business location close to Baubau City with a score of 0.68 and the biggest weakness is limited capital and lack of market promotion activities. with a score of 0.33 . This is the need to improve promotional strategies by utilizing social media internet as a medium to develop business. While the EFE (External Factor Evaluation) matrix analysis shows that the biggest opportunity in the distribution of tilapia marketing is the existence of business development from the government and academia, and the biggest threat in the distribution of tilapia marketing is disease attacks that can reduce the quality and quantity of tilapia and increase the price of fish feed. indigo with a score of 0.22 .

\section{SWOT Ranking}

Tabel 7. Rangking strategi pengembangan usaha budidaya ikan nila.

\begin{tabular}{|l|l|c|c|c|}
\hline No & \multicolumn{1}{|c|}{ Strategy } & Value & Total Score & Ranking \\
\hline 1 & SO (Strengths-Opportunities) & $1,96+1,40$ & 3,36 & I \\
\hline 2 & ST (Strengths-Threats) & $1,96+0,71$ & 2,67 & II \\
\hline 3 & $\begin{array}{l}\text { WO (Weakness- } \\
\text { Opportunities) }\end{array}$ & $1,22+1,40$ & 2,62 & III \\
\hline 4 & WT (Weakness- Threats) & $1,22+0,71$ & 1,93 & IV \\
\hline
\end{tabular}

Based on the table above, it shows that the highest SWOT ranking results are in the SO (Strengths-Opportunities) strategy with a total score of 3.36. SO strategy is a strategy that creates all strengths $(\mathrm{S})$ to take advantage of opportunities $(\mathrm{O})$ in the development of tilapia aquaculture in the Liabuku District, Bungi District, Baubau City.

\section{Strategy and policy formulation}

The strategy and policy analysis used is the SWOT matrix which is a tool to systematically identify factors, both internal factors which include strengths and weaknesses and external factors which include opportunities and threats that are currently faced. The results of the SWOT analysis formulation are:

Table 8. Formulation of Strategy for Tilapia Cultivation Business Development in Liabuku Village, Bungi District, Baubau City.

\begin{tabular}{|c|c|c|}
\hline External & $\begin{array}{l}\text { Power - S } \\
\text { 1. The area of cultivated } \\
\text { business land is very } \\
\text { adequate; } \\
\text { 2. The potential of natural } \\
\text { resources } \\
\text { Support; } \\
\text { 3. Very strategic } \\
\text { business location } \\
\text { close to Baubau }\end{array}$ & $\begin{array}{l}\text { Weaknesses - W } \\
\text { 1. Capital Limitations; } \\
\text { 2. Tilapia enlargement business } \\
\text { land is not certified; } \\
\text { 3. Lack of market promotion } \\
\text { activities; } \\
\text { 4. Financial management is not } \\
\text { good. } \\
\text { 5. Lack of knowledge and } \\
\text { mastery of new }\end{array}$ \\
\hline
\end{tabular}

Copyright $\odot$ 2022, Journal of Asian Multicultural Research for Economy and Management Study, Under the license CC BY-SA 4.0 


\begin{tabular}{|c|c|c|}
\hline & $\begin{array}{l}\text { City; } \\
\text { 4. Social relationships with } \\
\text { consumers are good. }\end{array}$ & technologies. \\
\hline $\begin{array}{l}\text { Opportunity - O } \\
\text { 1. High demand for } \\
\text { Tilapia fish; } \\
\text { 2. The existence } \\
\text { of business } \\
\text { development } \\
\text { both from the } \\
\text { government } \\
\text { and academia; } \\
\text { 3. The market } \\
\text { opportunity is huge; } \\
\text { 4. Good } \\
\text { relationship } \\
\text { with } \\
\text { stakeholders } \\
\text {. }\end{array}$ & $\begin{array}{l}\text { Strategists } \mathbf{S - O} \\
\text { 1. Increase tilapia production } \\
\text { to meet market demand; } \\
\text { 2. Maximize the use of } \\
\text { available land to } \\
\text { increase production; } \\
\text { 3. Cooperate with } \\
\text { governmental } \\
\text { organizations or } \\
\text { companies to assist in } \\
\text { production and } \\
\text { marketing activities; } \\
\text { 4. Increase cooperation with } \\
\text { stakeholders to improve } \\
\text { technological and } \\
\text { information knowledge. }\end{array}$ & $\begin{array}{l}\text { W-O Strategy } \\
\text { 1. Applying for business capital } \\
\text { a s is t an ce to the } \\
\text { government or organization } \\
\text { support to carry out the } \\
\text { enlargement of tilapia fish; } \\
\text { 2. Attend talkshows or } \\
\text { exhibitions to enhance } \\
\text { market promotion } \\
\text { knowledge and strategies; } \\
\text { 3. Using internet social media } \\
\text { and holding exhibitions of } \\
\text { processed tilapase products } \\
\text { as a form of business } \\
\text { promotion; } \\
\text { 4. Utilizing counseling from } \\
\text { fisheries extension officers } \\
\text { to improve technology } \\
\text { mastery capabilities, } \\
\text { access } \\
\text { market and good financial } \\
\text { management. }\end{array}$ \\
\hline $\begin{array}{l}\quad \text { Threat - T } \\
\text { 1. Disease attacks } \\
\text { that can decrease } \\
\text { the quality and } \\
\text { quantity of } \\
\text { tilapia fish; } \\
\text { 2. Increase in the price } \\
\text { of tilapia feed; } \\
\text { 3. Difference in the } \\
\text { price of tilapia } \\
\text { from other } \\
\text { villages / regions; } \\
\text { 4. Competition } \\
\text { Market demand } \\
\text { for certain types } \\
\text { of tilapia. }\end{array}$ & $\begin{array}{l}\text { S-T Strategy } \\
\text { 1. Cultivating with different } \\
\text { types of tilapia fish; } \\
\text { 2. Increase the production of } \\
\text { tilapia seedlings; } \\
\text { 3. Doing seeding to meet } \\
\text { business needs. }\end{array}$ & $\begin{array}{l}\text { W-T Strategy } \\
\text { 1. Improving the quality } \\
\text { of seeding resources } \\
\text { technically to } \\
\text { maximize the production } \\
\text { and competitiveness of } \\
\text { tilapia fish by means of } \\
\text { extension and adoption of } \\
\text { hatchery technology; } \\
\text { 2. Producing tilapia with } \\
\text { different qualities so that } \\
\text { consumers have } \\
\text { More choices. }\end{array}$ \\
\hline
\end{tabular}




\section{SWOT Quadrant}

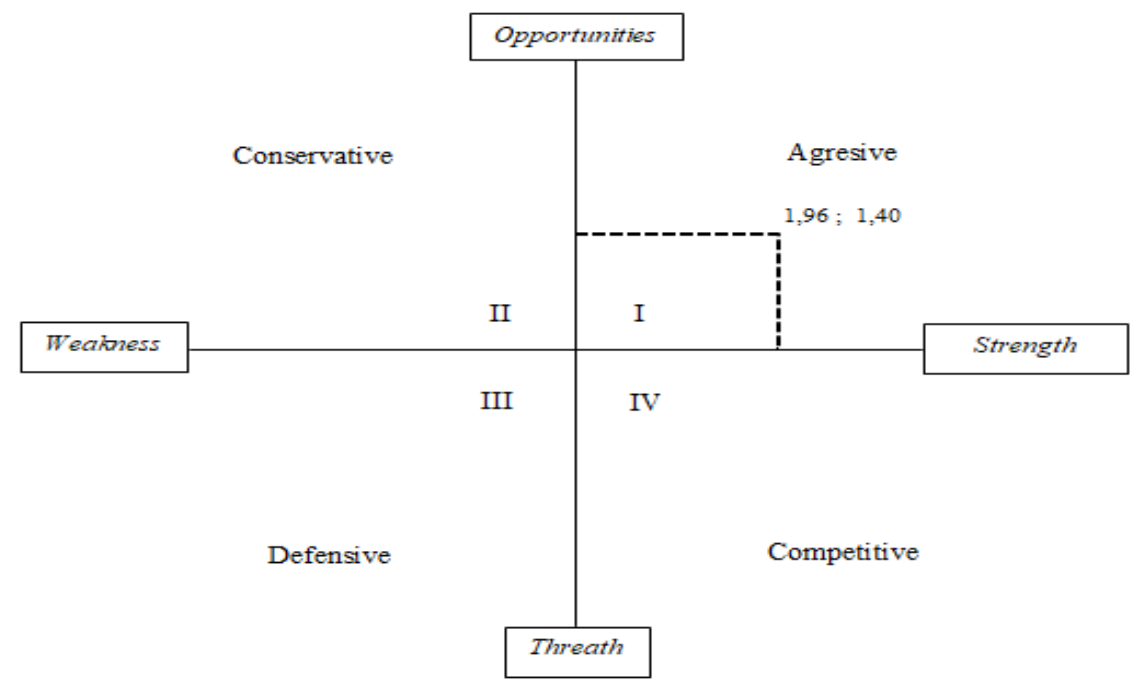

Figure 1. Strategy Quadrant of Tilapia Cultivation Business Development in Liabuku Village, Bungi District, Baubau City

Based on the results of the SWOT quadrant image, it shows that the coordinates are determined by comparing the total score on internal factors with the total score on external factors. The results show that the condition of tilapia cultivation is in quadrant I, which is aggressive, meaning that this condition is very favorable to support the strategy of developing tilapia cultivation because the position of quadrant I has strengths and opportunities that can be exploited to minimize weaknesses and threats. Strategies that can be carried out are maximizing land use to increase production, promoting collaboration with the government and nongovernmental organizations (NGOs) or partners, establishing cooperative savings and loans together, and utilizing counseling from extension officers or academics to improve technology mastery capabilities, market access and good financial management.

\section{Conclusion}

Tilapia marketing distribution level in channel II pattern (Producer-Retailer-Final Consumer) is dominantly used because the marketing distribution channel is relatively shorter so that it cuts the marketing distribution channel to reach the final consumer level, so as to reduce other additional costs. This can be seen based on the share value obtained by $40 \%$ where this value shows benefits for tilapia fish pond farmers (producers) who are promising as tilapia fish farming business actors. Meanwhile, channel I (Final Producer-Consumer) pattern is better because this pattern is direct or not through intermediaries, so it does not require other additional costs, on the other hand it is more profitable for end consumers by getting cheaper prices. The marketing margin is relatively constant, ranging from $\mathrm{Rp}$. 3,000, - per head (seedling) up to Rp. 5.000,- per head (seedling). This marketing margin is significantly influenced by marketing volume, costs such as the cost of pool water Rp. 550,- with distribution margin $18.34 \%$, share $11 \%$, oxygen cost Rp. 625 ,- margin distribution is $20.83 \%$, share is $12.5 \%$, plastic cost is $325,-$ margin distribution is $10.83 \%$ and share is $6.5 \%$. Meanwhile, wholesalers still incur costs such as the cost of pool water of Rp. 556,- distribution margin $11.12 \%$, share $7.94 \%$, oxygen cost Rp. 217 ,- distribution margin $4.34 \%$, share $3.1 \%$, plastic cost Rp. 127,- distribution margin $2.54 \%$, share $1.81 \%$ and profit Rp. 1,100, distribution margin $22 \%$, share $15.71 \%$. Analysis of the strategy and policy matrix shows that the condition of tilapia cultivation is in quadrant I which tends to support the S-O strategy, 
which is aggressive, meaning that this condition is very favorable to support the strategy of developing fish farming business. Strategies that can be carried out are maximizing land use to increase production, promoting collaboration with the government and non-governmental organizations (NGOs) or partners, establishing cooperative savings and loans together, and utilizing counseling from extension officers or academics to improve technology mastery capabilities, market access and good financial management.

\section{Thank-You Note}

We express our sincere gratitude for the cooperation and dedication to the Chancellor of the University of Muhammadiyah Buton, the Dean of the Faculty of Agriculture at the University of Muhammadiyah Buton, the Chair of the Aquatic Resources Management Study Program, Faculty of Agriculture, University of Muhammadiyah Buton, along with all parties involved in the preparation of the research article with the title "Marketing Distribution Analysis. Tilapia (Oreochromis nilothicus) in Liabuku Village, Bungi District, Baubau City (Case Study: In the case of Mr. Hamzah's production house).

\section{Funding}

The source of the funding comes from the University of Muhammadiyah Buton's Budget for $2021 / 2022$.

\section{References}

Ahmed, N., \& Turchini, G. M. (2021). The evolution of the blue-green revolution of rice-fish cultivation for sustainable food production. Sustainability Science, 1-16.

Ashlagi, I., Burq, M., Jaillet, P., \& Saberi, A. (2018). Maximizing efficiency in dynamic matching markets. arXiv preprint arXiv:1803.01285.

Innis, S. M. (2008). Dietary omega 3 fatty acids and the developing brain. Brain research, $1237,35-43$.

Nigam, D., Yadav, R., \& Tiwari, U. (2018). Omega-3 fatty acids and its role in human health. In Functional food and human health (pp. 173-198). Springer, Singapore.

Pilar, P. G., Marta, A. P., \& Antonio, A. (2018). Profit efficiency and its determinants in small and medium-sized enterprises in Spain. BRQ Business Research Quarterly, 21(4), 238-250.

Santos, H. O., Earnest, C. P., Tinsley, G. M., Izidoro, L. F., \& Macedo, R. C. (2020). Small dense low-density lipoprotein-cholesterol (sdLDL-C): Analysis, effects on cardiovascular endpoints and dietary strategies. Progress in cardiovascular diseases, 63(4), 503-509.

Singh, J. E., Babshetti, V., \& Shivaprasad, H. N. (2021). Efficient Market Hypothesis to Behavioral Finance: A Review of Rationality to Irrationality. Materials Today: Proceedings.

Szuwalski, C., Jin, X., Shan, X., \& Clavelle, T. (2020). Marine seafood production via intense exploitation and cultivation in China: costs, benefits, and risks. PloS one, 15(1), $\mathrm{e} 0227106$.

Yuliyarabihati, Y., Mahreda, E. S., \& Febrianty, I. (2014). Analisis Pemasaran Dan Distribusi Ikan Nila Segar (Oreochromis Niloticus) Di Pasar Bauntung Banjarbaru Provinsi Kalimantan Selatan. EnviroScienteae, 12(2), 137-143. 